\title{
IMPLEMENTASI KEBIJAKAN POLA KARIER PEGAWAI NEGERI SIPIL PADA BADAN KEPEGAWAIAN DAN PENGEMBANGAN SUMBER DAYA MANUSIA KABUPATEN SERANG PROVINSI BANTEN
}

\author{
Oleh \\ Rizky Akbar ${ }^{1}$, \\ Muh. Ilham², Deti Mulyati ${ }^{3}$ \\ 1) Institut Pemerintahan Dalam Negeri \\ Program Magister Terapan Studi Pemerintahan Daerah Institut Pemerintahan Dalam Negeri \\ akbarr3009@yahoo.com \\ ${ }^{2,3)}$ Institut Pemerintahan Dalam Negeri
}

\begin{abstract}
"IMPLEMENTATION OF CIVIL SERVANT CAREER PATTERN POLICY IN THE SERVICE AGENCY AND HUMAN RESOURCES DEVELOPMENT, SERANG REGENCY, BANTEN PROVINCE"
\end{abstract}

Career patterns in positions guarantee work peace by referring to the performance of employees who can determine their own careers according to their ability es and competencies. The pattern of coaching for civil servants describes the career development path that shows the relationship and harmony between positions, ranks, education, and job training, competencies and tenure of employees from the beginning of appointment to retirement. Researchers focus on the implementation of career pattern policies at BKPSDM Serang Regency. The purpose of the study was to describe how the placement of employees with the policy of career patterns, to find out why and what strategies were carried out by BKPSDM Serang Regency.

This study uses a descriptive method with a qualitative approach using Edward III's implementation theory with primary and secondary data sources, describing the implementation of career pattern policies so that a career pattern implementation strategy is made with the conditions that exist in BKPSDM Serang Regency.

Based on the results of the study, it can be concluded that first, the implementation of career pattern policies at the BKPSDM Serang Regency there are still deviant things so that the process of employee career patterns has not run optimally. Second, the strategy carried out by the internal environment with transparency and lack of budget and the strategy carried out by the external environment with clear regulations and the absence of a national scale pilot project. Suggestions that need to be considered by local governments, especially BKPSDM Serang Regency, are optimizing career pattern policies, increasing budgets, clear regulations and making BKPSDM a pilot project on a national scale.

Keywords: policy implementation, career patterns, policy strategies

\section{AbSTRaK}

$\mathrm{P}$ ola Karier dalam jabatan menjamin ketenangan kerja dengan mengacu kinerja pegawai yang dapat menentukan kariernya sendiri sesuai dengan kemampuan dan kompetensi yang 
dimiliki. Pola pembinaan PNS menggambarkan alur pengembangan karier yang menunjukkan keterkaitan dan keserasian antar jabatan, pangkat, pendidikan, dan pelatihan jabatan, kompetensi serta masa jabatan pegawai dari awal pengangkatan sampai pensiun. Peneliti mengambil fokus pada implementasi kebijakan pola karier pada BKPSDM Kabupaten Serang. Tujuan penelitian ini adalah untuk menggambarkan bagaimana penempatan pegawai dengan adanya kebijakan pola karier, untuk mengetahui mengapa dan strategi apa saja yang dilakukan BKPSDM Kabupaten Serang.

Penelitian ini menggunakan metode kualitatif deskriptif dengan pendekatan deduktif yang di dalamnya menggunakan teori implementasi Edward III dengan sumber data primer dan sekunder, serta menggambarkan implementasi kebijakan pola karier sehingga dapat dibuat strategi pelaksanaan pola karier dengan kondisi yang ada di BKPSDM Kabupaten Serang.

Berdasarkan hasil penelitian dapat disimpulkan bahwa implementasi kebijakan pola karier pada BKPSDM Kabupaten Serang masih terdapat hal-hal menyimpang sehingga proses pola karier pegawai belum berjalan optimal. Kemudian strategi yang dilakukan di lingkungan internal dengan transparansi dan minimnya anggaran, sedangkan strategi yang dilakukan di lingkungan eksternal dengan regulasi yang jelas namun, belum adanya pilot project berskala nasional. Saran yang perlu diperhatikan oleh pemerintah daerah khususnya BKPSDM Kabupaten Serang, yaitu optimalisasi kebijakan pola karier, peningkatan anggaran, regulasi yang jelas dan menjadikan BKPSDM sebagai pilot project berskala nasional.

Kata kunci: implementasi kebijakan, pola karier, strategi kebijakan

\section{PENDAHULUAN}

$\mathrm{P}$ enyelenggaraan Pemerintah Daerah sesuai dengan Undang-Undang No. 23 Tahun 2014 tentang Pemerintahan Daerah dan Undang-Undang No. 5 Tahun 2014 tentang Aparatur Sipil Negara, merupakan acuan dasar bahwa Aparatur Sipil Negara harus memiliki integritas, profesional dan bebas dari intervensi politik serta bebas dari praktik korupsi, kolusi dan nepotisme serta mampu menyelenggarakan pelayanan publik yang baik merupakan bagian dari reformasi birokrasi. Salah satu sub permasalahan dalam reformasi birokrasi adalah permasalahan sumber daya manusia. Pegawai Negeri Sipil sebagai sumber daya manusia dalam birokrasi publik dianggap mempunyai andil besar dalam hal terjadinya Korupsi, Kolusi dan Nepotisme, semua itu terjadi karena PNS masih dianggap sebagai alat perpanjangan tangan oleh penguasa politik, hal itu sangat penting untuk ditangani dalam penyelenggaraan pemerintahan daerah.
Promosi PNS dilakukan berdasarkan perbandingan objektif antara kompetensi, kualifikasi dan persyaratan yang dibutuhkan oleh jabatan, penilaian atas prestasi kerja, kepemimpinan, kerja sama, kreativitas, dan pertimbangan dari tim penilai kinerja. Sistem pengembangan karier yang dilakukan pada Badan Kepegawaian dan Pengembangan Sumber Daya Manusia Kabupaten Serang mengacu pada Peraturan Bupati No. 68 Tahun 2017 tentang Pedoman Pola Karier di Lingkungan Pemerintahan Kabupaten Serang, dalam rangka pengembangan pegawai Badan Kepegawaian dan Pengembangan Sumber Daya Manusia Kabupaten Serang memiliki pola karier instansional dan antar instansional sesuai dengan kebutuhan Pemerintahan Daerah yang terintegrasi secara nasional serta harus memenuhi unsur pola karier sebagaimana diatur dalam Pasal 4 Peraturan Bupati No. 68 Tahun 2017.

Dalam penelitian ini, penulis telah melakukan pengamatan awal terkait isu-isu permasalahan yang terjadi di Kabupaten Serang, yaitu masih banyak Pegawai Negeri 
Sipil yang diangkat oleh pejabat politik yang lama diganti oleh pejabat politik yang baru tanpa mempertimbangkan kemampuan, keahlian dan latar belakang pendidikan yang dimiliki PNS tersebut. Bahkan dalam pelaksanaan promosi jabatan yang lebih tinggi, dilakukan atas dasar nepotisme atau atas dasar like and dislike. Ketidaksiapan PNS Kabupaten Serang juga dikarenakan kurangnya adanya keleluasaan untuk mengikuti pengembangan pendidikan dan pelatihan dikarenakan terbatasnya anggaran sehingga terjadi kejadian seorang pejabat menduduki jabatannya terlebih dahulu baru diberikan pembekalan tambahan. Penempatan pegawai untuk memenuhi tugas dari masing-masing unit organisasi di Kabupaten Serang sebenarnya telah diatur berdasarkan Peraturan Bupati No. 68 Tahun 2017 mulai dari jabatan pelaksana hingga jabatan pimpinan tinggi pratama, namun di lapangan meskipun beberapa kriteria telah dipenuhi, promosi jabatan tetap menjadi kewenangan kepala daerah sepenuhnya.

\section{Identifikasi Masalah}

Berdasarkan latar belakang di atas maka dapat diidentifikasi permasalahan antara lain:

1. Belum terlaksana pola karier PNS di Badan Kepegawaian dan Pengembangan Sumber Daya Manusia Kabupaten Serang.

2. Tidak terdapat calon yang sesuai atau memenuhi syarat untuk menduduki suatu jabatan (proses kaderisasi belum dilakukan dengan baik).

3. Penempatan PNS di BKPSDM dalam suatu jabatan masih ada yang belum sesuai dengan kapasitasnya.

4. Kurangnya kesempatan aparatur dalam pengembangan diri yang di dukung oleh Pemerintahan Daerah.

\section{Perumusan Masalah}

Berdasarkan latar belakang dan identifikasi masalah tersebut, maka penulis merumuskan pokok permasalahan penelitian pada Badan Kepegawaian dan Pengembangan Sumber Daya Manusia (BKPSDM) Kabupaten Serang sebagai berikut.

1. Bagaimana Implementasi Kebijakan Pola Karier Pegawai Negeri Sipil pada BKPSDM di Kabupaten Serang

2. Strategi apa yang digunakan Badan Kepegawaian Pemberdayaan Sumber Daya Manusia dalam Implementasi Kebijakan Pola Karier Pegawai Negeri Sipil di BKPSDM Kabupaten Serang Provinsi Banten.

\section{Maksud dan Tujuan Penelitian}

berikut.

Maksud penelitian adalah sebagai

1. Untuk mengetahui bagaimana pola karier Pegawai Negeri Sipil pada Badan Kepegawaian dan Pengembangan Sumber Daya Manusia Kabupaten Serang.

2. Untuk mengetahui strategi apa saja yang dilakukan Badan Kepegawaian Pemberdayaan Sumber Daya Manusia dalam pola karier Pegawai Negeri Sipil di Kabupaten Serang.

Adapun tujuan dari penelitian ini adalah untuk mengetahui bagaimana dan hambatan apa serta upaya yang dilaksanakan dalam Implementasi Pola Karier Pegawai pada Badan Kepegawaian dan Pengembangan Sumber Daya Manusia di Kabupaten Serang Provinsi Banten serta memperoleh deskripsi dan gambaran pola karier dengan cara menganalisis, apakah pola karier sudah diterapkan dan dilaksanakan dengan baik oleh Badan Kepegawaian dan Pengembangan Sumber Daya Manusia, menganalisis kesuksesan terkait pola karier yang diterapkan di Kabupaten Serang.

\section{KAJIAN PUSTAKA}

Pola karier Pegawai Negeri Sipil memiliki peran penting dalam rangka meningkatkan 
kualitas sumber daya aparatur dan kualitas kinerja organisasi pemerintahan, Pengembangan karier Pegawai Negeri Sipil ini menjadi daya tarik tersendiri bagi peneliti untuk melakukan kajian dan Analisis yang lebih mendalam. Penelitian terdahulu dapat dijadikan sebagai referensi yang mengarahkan penelitian ini agar lebih fokus pada hal-hal pokok penelitian ini. Ada beberapa yang dijadikan rujukan bagi penulis untuk meneliti, antara lain:

1. Pada 2010, Achmad Mulyana melakukan penelitian mengenai "Sistem Karier dan Mutasi Pegawai Negeri Sipil pada Sekretariat Daerah Kabupaten Pidie Provinsi Aceh".

2. Pada 2015, Nur Efendi melakukan penelitian dengan judul: "Pengembangan Sumber Daya Manusia Berbasis Kompetensi di Kantor Pemerintah Kota Bandar Lampung".

3. Pada 2017, Raden Y. P. Setiadiputra dalam jurnalnya melakukan penelitian dengan Judul: "Urgensi Program Pengembangan Kompetensi SDM Secara Berkesinambungan di Lingkungan Instansi Pemerintah".

Pelaksanaan atau implementasi kebijakan bersangkut paut dengan ikhtiarikhtiar untuk mencapai tujuan dari ditetapkannya suatu kebijakan tertentu, tahap ini pada dasarnya berkaitan dengan bagaimana pemerintah bekerja atau proses yang dilakukan oleh pemerintah untuk menjadikan kebijakan menghasilkan keadaan yang direncanakan. Menurut Ripley dan Franklin mengartikan "implementasi sebagai apa yang terjadi setelah undangundang ditetapkan yang memberikan otoritas program, kebijakan, keuntungan (benefit), atau suatu jenis keluaran yang nyata (tangible output)".

Model implementasi yang dikemukakan oleh Edward III pada 1980 dalam Subarsono (2016: 90) merupakan yang paling cocok dengan penelitian ini, karena teori ini memiliki dasar jalannya pemerintahan di daerah, yaitu komunikasi, sumber daya, disposisi, dan struktur birokrasi. Di dalam pemerintahan dibutuhkan komunikasi yang baik untuk dapat menyampaikan tujuan maupun maksud dari jalannya pemerintahan, yaitu kebijakan terkait pembangunan daerah, baik itu antar pemangku kepentingan, antar pegawai maupun komunikasi yang terjadi antara pegawai atau pejabat daerah dengan masyarakat luas.

Untuk dapat menyampaikan komunikasi yang baik diperlukan sumber daya manusia yang mumpuni, agar tidak terjadi kesalahan dalam penyampaian maksud dan tujuan kebijakan agar tidak terjadi konflik, baik antara pegawai dengan pejabat atau pemangku kepentingan, maupun dengan masyarakat selaku penerima manfaat dari pembangunan yang dilakukan. Disposisi diperlukan, agar sumber daya yang ada mau dan mampu mengerti atas tujuan yang diambil dari sebuah kebijakan.

Struktur birokrasi merupakan hal penting dalam pemerintahan di daerah, karena sebuah kebijakan memerlukan sebuah struktur birokrasi agar dapat diketahui siapa yang bertanggung jawab atas sebuah kebijakan yang diambil, dan siapa yang melaksanakan kebijakan tersebut.

\section{METODE PENELITIAN}

Pada penelitian ini, peneliti menggunakan metode kualitatif deduktif dengan pendekatan deskriptif. Menurut Creswell, penelitian kualitatif merupakan metode-metode untuk menguji teori-teori tertentu dengan cara meneliti hubungan antarvariabel. Metode kualitatif menurut Bogdan \& Guba dalam Suharsaputra adalah prosedur penelitian yang menghasilkan data deskriptif berupa kata-kata tertulis atau lisan dari orang-orang dan perilaku yang diamati. Metode deskriptif menurut Nazil, adalah suatu metode dalam meneliti status sekelompok manusia, suatu objek, suatu set kondisi, suatu sistem 
pemikiran, ataupun suatu kelas peristiwa masa sekarang. Menurut Sumanto, Penelitian deskriptif berusaha mendeskripsikan dan menginterpretasi apa yang ada (bisa mengenai kondisi atau hubungan yang ada, pendapat yang sedang tumbuh, proses yang sedang berlangsung, akibat atau efek yang terjadi, atau kecenderungan yang tengah berkembang).

Guna terciptanya pola karier yang baik di Badan Kepegawaian Pengembangan Seumber Daya Manusia, maka strategi yang menggunakan analisis SWOT merupakan analisis yang berdasarkan pada anggapan bahwa suatu strategi yang efektif berasal dari sumber daya internal (strengths dan weakness) dan eksternal (opportunity dan threat). Keuntungan dari analisis SWOT adalah menghubungkan faktor internal dan eksternal untuk merangsang strategi baru, oleh karena itu perencanaan yang berdasarkan pada sumber daya dan kompetensi dapat memperkaya analisis SWOT dengan mengembangkan perspektif internal (Dyson, 2002).

Kerangka konseptual penelitian merupakan perangkat penyusunan pedoman wawancara penelitian kualitatif dalam rangka mempermudah peneliti dalam pengumpulan informasi dan data di lapangan. Berikut diuraikan kerangka konseptual tersebut dalam penelitian ini.

Peneliti akan mengumpulkan data dari informan yang berkaitan dengan Implementasi Kebijakan Pola Karier Pegawai Negeri Sipil pada Badan Kepegawaian

Tabel 1. Kerangka Konseptual Penelitian

\begin{tabular}{|c|c|c|}
\hline KONSEP & DIMENSI & INDIKATOR \\
\hline \multirow{10}{*}{$\begin{array}{l}\text { Implementasi } \\
\text { (Edward III 1980) }\end{array}$} & \multirow[t]{3}{*}{ Komunikasi } & 1. Transmisi \\
\hline & & 2. Kejelasan \\
\hline & & 3. Konsistensi \\
\hline & \multirow[t]{3}{*}{ Sumber Daya } & 1. Staf \\
\hline & & 2. Wewenang \\
\hline & & 3. Informasi \\
\hline & \multirow[t]{2}{*}{ Disposisi } & 1. Syarat Birokrasi \\
\hline & & 2. Insentif \\
\hline & \multirow[t]{2}{*}{ Struktur Birokrasi } & 1. SOP \\
\hline & & 2. Fragmentasi \\
\hline \multirow[t]{10}{*}{ SWOT } & Strengths & 1. UU ASN No. 5 Tahun 2014 \\
\hline & \multirow{2}{*}{$\begin{array}{l}\text { (Kekuatan/ } \\
\text { Ketangguhan) }\end{array}$} & 2. Panduan Pola Karier \\
\hline & & 3. Manajemen PNS \\
\hline & \multirow{3}{*}{$\begin{array}{l}\text { Weakness } \\
\text { (Kelemahan) }\end{array}$} & 1. Faktor penghambat \\
\hline & & 2. Anggaran \\
\hline & & 3. Peta jabatan \\
\hline & Opportunity & 1. Hal positive \\
\hline & (Peluang) & 2. Lembaga pengawas formal dan non formal \\
\hline & Threats & 1. Kondisi Politik \\
\hline & (Ancaman) & 2. Komitmen \\
\hline
\end{tabular}

Sumber: Diolah oleh Peneliti, 2020 
Pemberdayaan Sumber Daya Manusia Kabupaten Serang Provinsi Banten. Rencana informan berjumlah 8 orang yang terdiri dari:

1. Kepala BKPSDM Kabupaten Serang,

2. Sekretaris BKPSDM Kabupaten Serang,

3. Kepala Bidang Pengembangan Karier,

4. Kepala Subbidang Analisis dan Evaluasi Pendidikan dan Pelatihan,

5. Kepala Bidang Administrasi Pegawai,

6. Kepala Subbidang Promosi dan Mutasi Jabatan,

7. Kepala Subbidang Diklat Jabatan Struktural dan

8. Staf BKPSDM.

\section{Teknik Pengumpulan Data}

Penelitian ini menggunakan metode penelitiankualitatif, menurutCreswell(2010: 267) prosedur-prosedur pengumpulan data dalam penelitian kualitatif melibatkan empat jenis strategi, antara lain:

Observasi kualitatif merupakan observasi yang di dalamnya peneliti langsung turun kelapangan untuk mengamati perilaku dan aktivitas individu-individu di lokasi penelitian.

Dalam wawancara kualitatif, peneliti dalam melakukan face-to-face interview (wawancara berhadap-hadapan) dengan partisipan, mewawancara mereka dengan telepon, atau terlibat dalam focus group interview (interview dalam kelompok tertentu) yang terdiri dari enam sampai delapan partisipan per kelompok.

Selama proses penelitian, peneliti juga mengumpulkan dokumen-dokumen kualitatif. Dokumen ini bias berupa dokumen public (serta Koran, makalah, laporan kantor) ataupun dokumen privat (seperti, buku harian, diary, surat, e-mail)

Kategori terakhir dari data kualitatif adalah materi audio dan visual. Data ini bias berupa foto, objek-objek seni, video tape, atau segala jenis suara/bunyi.

\section{- Wawancara (Interview)}

Metode pengumpulan data melalui wawancara, dalam penelitian kualitatif umumnya dimaksudkan untuk mendalami dan lebih mendalami suatu kejadian dan atau kegiatan subjek penelitian. Pada penelitian ini, peneliti menggunakan teknik wawancara terstruktur, yang mana peneliti telah membuat pedoman wawancara yang pertanyaannya disusun terlebih dahulu sebelum melakukan wawancara.

\section{- Observasi}

Pada pengamatan ini, peneliti melakukan pengamatan terhadap implementasi kebijakan pola karier dalam hal ini Pegawai untuk melaksanakan analisis jabatan,evaluasi jabatan, menetapkan peta jabatan dan menetapkan standar kompetensi jabatan yang akan disajikan oleh Badan Kepegawaian Pengembangan Sumber Daya Manusia dan juga peneliti akan langsung turun ke lapangan/ke lokasi penelitian, yaitu di Kabupaten Serang Provinsi Banten.

\section{- Dokumentasi}

Dokumen menurut Suharsaputra merupakan rekaman kejadian masa lalu yang ditulis atau dicetak merek dalam berupa catatan annecdot, surat, buku harian, dan dokumen-dokumen. Selanjutnya menurut Simangunsong selain melalui wawancara dan observasi, informasi juga bisa diperoleh lewat fakta yang tersimpan dalam bentuk surat, catatan harian, foto, hasil rapat, cendera mata, jurnal kegiatan, dan sebagainya.

\section{Teknik Analisis Data}

Analisis data yang dilakukan meliputi mereduksi data, menyajikan data, displai data, menarik simpulan dan melaksanakan verifikasi. Berkaitan dengan penelitian ini, 
data yang dikumpulkan selanjutnya diolah dan dianalisis secara kualitatif menggunakan langkah sebagai berikut.

1. Mereduksi, data adalah proses pengolahan data dari lapangan dengan memilah dan memilih, dan menyederhanakan data dengan merangkum yang penting-penting sesuai dengan fokus masalah penelitian.

2. Menyajikan Data (Displai), untuk lebih menyistematiskan data yang telah direduksi sehingga terlihat sosoknya yang lebih utuh. Dalam displai data, laporan yang sudah di reduksi dilihat kembali gambaran secara keseluruhan, sehingga dapat tergambar konteks data secara keseluruhan, dan dari situ dapat dilakukan penggalian data kembali apabila dipandang perlu untuk lebih mendalami masalahnya.

3. Menarik simpulan, merupakan alur ketiga, yaitu menarik simpulan dan verifikasi terjadi ketika penganalisis mulai mencari kecocok-cocokan, polapola, konfigurasi-konfigurasi yang saling keterkaitan dan menunjukkan sebab akibat. Simpulan diverifikasi selama penelitian berlangsung, setingkat pemikiran kembali yang melintas dalam pikiran penganalisis selama ia menulis, serta merupakan peninjauan ulang kesepakatan intersubjektif.

\section{Lokasi Penelitian}

Penelitian ini dilaksanakan Badan Kepegawaian Pemberdayaan Sumber Daya Manusia di Kabupaten Serang Provinsi Banten.

Adapun pelaksanaan penelitian disesuaikan berdasarkan jadwal yang dilakukan melalui beberapa tahapan penelitian.

\section{HASIL DAN PEMBAHASAN}

\section{Implementasi Kebijakan Pola Karier PNS}

Implementasi Kebijakan berdasarkan teori George C. Edward III dalam winarno (2012:177) adalah salah satu tahap kebijakan publik, antara pembentukan kebijakan dan konsekuensi-konsekuensi kebijakan bagi masyarakat yang dipengaruhinya.

Dalam mengkaji implementasi kebijakan ada empat faktor/dimensi yang memengaruhi keberhasilan suatu implementasi kebijakan, yaitu komunikasi, birokrasi, sumber daya dan disposisi.

\section{- Komunikasi}

Komunikasi merupakan suatu kegiatan memberi dan menerima informasi dari

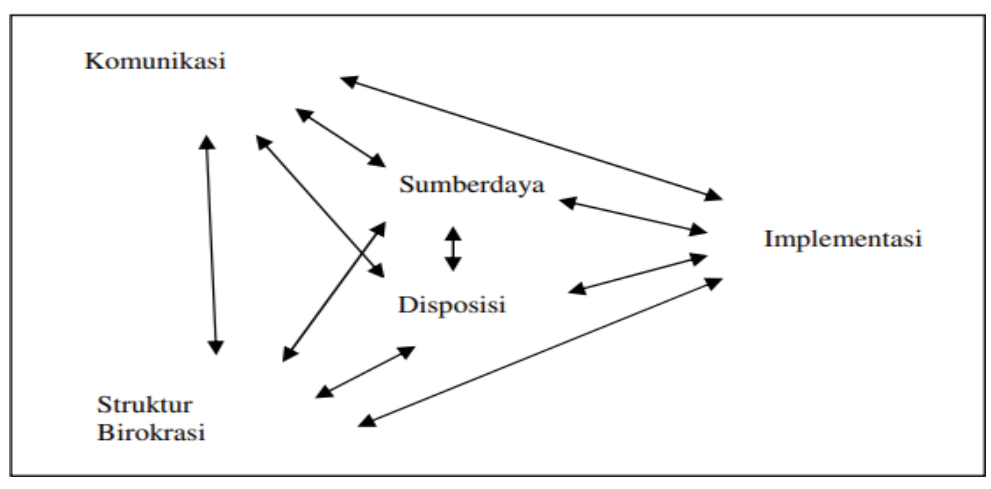

Gambar 1

Faktor Penentu Keberhasilan Implementasi Kebijakan menurut Edward III 
satu pihak ke pihak lainnya sehingga dapat tercapai pemahaman yang sama. Menurut Edward III dalam Widodo (2010: 97), Komunikasi diartikan sebagai "proses penyampaian informasi komunikator kepada komunikan".

Komunikasi kebijakan memiliki tiga dimensi yang dapat mengukur keberhasilan variabel komunikasi di antara lain adalah transmisi (transmission), kejelasan (clarity), dan konsistensi (consistency).

\section{- Sumber Daya}

Edward III dalam Widodo (2010: 98) mengemukakan bahwa faktor sumber daya mempunyai peranan penting dalam implementasi kebijakan.

Menurut Edward III dalam Widodo (2010: 98) bahwa sumber daya tersebut meliputi sumber daya manusia, sumber daya anggaran, dan sumber daya peralatan/ fasilitas dan sumber daya kewenangan.

\section{- Disposisi}

Faktor-faktor yang menjadi perhatian Edward III dalam Agustinus (2006: 159-160) mengenai disposisi dalam implementasi kebijakan terdiri dari pengangkatan birokrasi dan insentif.

\section{- Birokrasi}

Meskipun sumber-sumber untuk mengimplementasikan suatu kebijakan cukup dan para pelaksana (implementors) mengetahui apa dan bagaimana cara melakukannya, serta mempunyai keinginan untuk melakukannya, namun Edward III dalam Widodo (2010: 106) menyatakan bahwa "implementasi kebijakan bisa jadi masih belum efektif karena ketidakefisienan struktur birokrasi" di mana di dalamnya mencakup standar operasional prosedur (SOP) dan fragmentasi

\section{Strategi yang dilakukan BKPSDM Kabupaten Serang}

Untuk mendapatkan Strategi yang dapat dilakukan oleh BKPSDM Kabupaten Serang dalam Implementasi Kebijakan Pola Karier Pegawai Negeri Sipil, maka dalam penelitian ini peneliti menggunakan metode analisis SWOT (strengths, weakness, opportunities, dan threats). Analisis Analisis SWOT dilakukan terhadap dua jenis lingkungan, yaitu lingkungan internal dan lingkungan eksternal.

Berdasarkan dari matriks SWOT pada Tabel 1 dapat diketahui jika implementasi pola karier yang dilaksanakan di Kabupaten Serang kurang berhasil karena kurang tegasnya aturan yang diberikan pemerintah pusat, dan juga adanya perubahan aturan yang menggantikan pengembangan pola karier ke sistem merit.

\section{- Litmus Test}

Untuk mengukur seberapa nilai kestrategisan terhadap strategi-strategi yang telah dirumuskan melalui analisis SWOT, maka akan digunakan alat uji berupa litmus test sebagai alat bantu penilaian, Pengukuran nilai strategis suatu isu dengan menggunakan litmus test memerlukan klarifikasi pemberian nilai untuk masingmasing jawaban dengan kriteria sebagai berikut.

- Nilai 1 untuk jawaban bersifat operasional/tidak strategis;

- Nilai 2 untuk jawaban yang bersifat cukup strategis;

- Nilai 3 untuk jawaban yang bersifat strategis.

- $\quad$ Nilai tertinggi penilai per isu : 8 × $3=24$

- $\quad$ Nilai terendah penilai per isi : $8 \times 1=8$ 
Tabel 1 Matriks SWOT strategi yang dapat dilaksanakan BKPSDM Kabupaten Serang pada Implementasi pengembangan pola karier

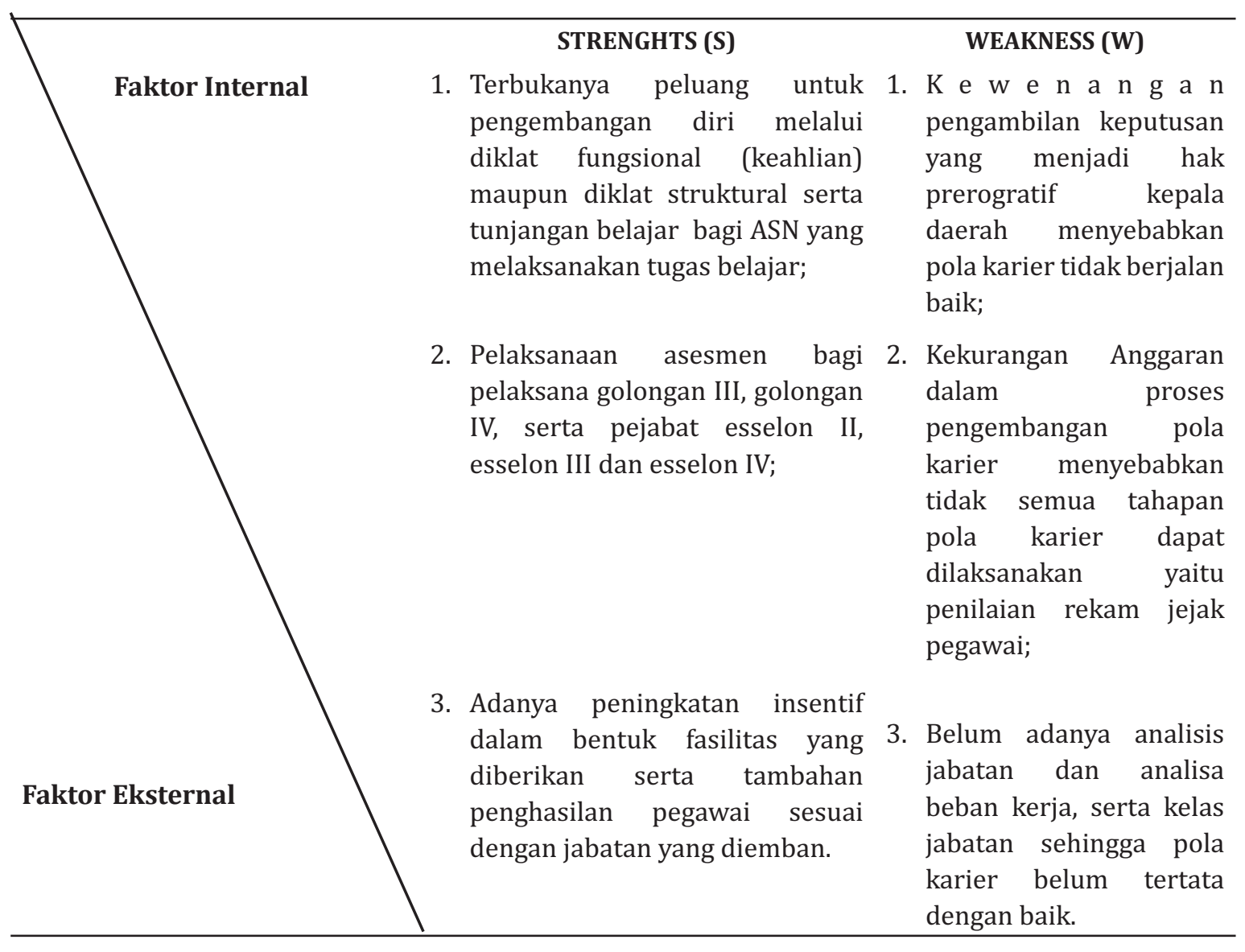

\section{OPPORTUNITIES (0)}

1. Aturan yang saling mendukung, UU no 23 tahun 2014, PermenPANRB no 13 tahun 2014 dan PerkaBKN no 35 tahun 2011 yang mengatur pengembangan pola karier;

2. Sistem pengawasan yang dilakukan oleh lembaga pemerintah yang lebih tinggi adanya;

3. Adanya transparansi dalam proses lelang jabatan yang di lakukan melalui media etak sejak awal proses lelang diumumkan hingga pengumuman pemenangan lelang.

\section{Startegi SO}

1. Melakukan sosialisasi terkait pentingnya pengembangan diri bagi pegawai dalam penerapan pola karier

2. Memperkuat aturan tentang pola karier yang sudah ada

3. Mengusulkan pengawasan ketat serta memberikan keterbukaan informasi dan pertanggung jawaban program.

\section{Strategi Wo}

1. Menciptakan pemahaman kepada pengambil kebijakan akan pentingnya implementasi kebijakan pola karier di BKPSDM Kabupaten Serang;

2. Mengusulkan penambahan anggaran untuk implementasi program pola karier;

3. Menciptakan inovasi melaksanakan analisis jabatan, analisis beban kerja, serta kelas jabatan. 


\section{THREATHS (T)}

1. Tidak adanya pilot project yang ditunjuk oleh pemerintahan pusat di tingkat nasional sehingga menyulitkan pemerintah daerah untuk menjakankan pengembangan pola karier;

2. Kurang tegasnya pemerintah pusat kepada daerah untuk menerapkan pengembangan pola karier;

\section{Strategi ST}

1. Mengusulkan kepada pemerintah pusat agar memberikan apresiasi kepada pemerintah daerah yang sudah menjalankan pola karier dengan baik;

2. Menambah pelatihan pengembangan karier pegawai harus menjadi motivasi pegawai dalam meraihnya dan tidak menimbulkan pemahaman pengembangan yang formalitas;

3. Menciptakan punishment bagi pemerintahan daerah yang melakukan kesalahan.

\section{Strategi WT}

1. Mengusulkan kegiatan analisis jabatan, analisa beban kerja, serta kelas jabatan pada tahun depannya dengan kesiapan anggaran yang memadai .

2. Berusaha mempertahankan kinerja dan mengembangi pola karier lingkup pemerintahan Kabupaten Serang dan menjadi Pilot Project berskala nasional;

3. Meningkatkan pola kerja dengan pengembangan e-goverment.

Sumber : Diolah oleh peneliti, 2020

Dengan memperhatikan skor serta nilai tertinggi dan nilai terendah, maka diperoleh range penilaian untuk seluruh jawaban informan terhadap delapan pertanyaan pada tiap-tiap strategis sebagai berikut.
- Skor Total 1-11 : Isu bersifat operasional

- Skor Total 12-21: Isu bersifat cukup strategis

- Skor Total 22-33: Isu bersifat sangat strategis

Tabel 2 Hasil Litmus Test Pada Rumusan Isu-isu Strategis

\begin{tabular}{clcr}
\hline No & \multicolumn{1}{c}{ Isu Strategis } & $\begin{array}{c}\text { Total } \\
\text { Skor }\end{array}$ & Kesimpulan \\
\hline 1. & $\begin{array}{l}\text { Melakukan sosialisasi terkait pentingnya pengembangan diri } \\
\text { bagi pegawai dalam penerapan pola karier }\end{array}$ & 29 & Isu sangat strategis \\
\hline 2. & Menyusun peraturan lanjutan tentang pola karier & 27 & Isu sangat strategis \\
\hline 3. & $\begin{array}{l}\text { Mengusulkan pengawasan ketat serta memberikan } \\
\text { keterbukaan informasi dan pertanggung jawaban program }\end{array}$ & 27 & Isu sangat strategis \\
\hline 4. & $\begin{array}{l}\text { Mengusulkan kepada pemerintah pusat agar memberikan } \\
\text { apresiasi kepada pemerintah daerah yang sudah menjalankan } \\
\text { pola karier dengan baik }\end{array}$ & 23 & Isu sangat strategis \\
\hline 5. & $\begin{array}{l}\text { Pelatihan pengembangan karier pegawai harus menjadi } \\
\text { motivasi pegawai dalam meraihnya dan tidak menimbulkan } \\
\text { pemahaman pengembangan yang formalitas }\end{array}$ & 26 & Isu sangat strategis \\
\hline 6. & $\begin{array}{l}\text { Menciptakan pemahaman kepada pengambil kebijakan akan } \\
\text { pentingnya implementasi kebijakan pola karier di BKPSDM } \\
\text { Kabupaten Serang }\end{array}$ & 27 & Isu sangat strategis \\
\hline
\end{tabular}




\begin{tabular}{llcc}
\hline 7. & $\begin{array}{l}\text { Mengusulkan penambahan anggaran agar terlaksananya } \\
\text { analisis jabatan, analisis beban kerja, serta kelas jabatan } \\
\text { yang di awasi lembaga pemerintah dengan mengedepankan } \\
\text { keterbukan informasi }\end{array}$ & 24 & Isu sangat strategis \\
\hline 8. & $\begin{array}{l}\text { Menciptakan inovasi melaksanakan analisis jabatan, analisis } \\
\text { beban kerja, serta kelas jabatan. }\end{array}$ & 25 & Isu sangat strategis \\
\hline 9. & $\begin{array}{l}\text { Mengusulkan kegiatan analisis jabatan, analisa beban kerja, } \\
\text { serta kelas jabatan pada tahun depannya dengan kesiapan } \\
\text { anggaran yang memadai }\end{array}$ & 26 & Isu sangat strategis \\
10. & $\begin{array}{l}\text { Berusaha mempertahankan kineja dan mengembangi pola } \\
\text { karier lingkup pemerintahan Kabupaten Serang dan menjadi } \\
\text { Pilot Project berskala nasional }\end{array}$ & 24 & Isu sangat strategis \\
\hline 11. Meningkatkan polakerja dengan pengembangan e-goverment. & 32 & Isu sangat strategis \\
\hline
\end{tabular}

\section{SIMPULAN}

Berdasarkan hasil wawancara, studi literatur dan pengamatan yang dilakukan penulis serta beberapa hasil analisis diuraikan dari Bab sebelumnya telah sesuai dengan teori Edward III oleh karena itu dapat kita simpulkan beberapa hal sebagai berikut.

1. Strategi yang dilakukan dalam Implementasi Kebijakan Pola Karier Pegawai Negeri Sipil Badan Kepegawaian Pengembangan Sumber Daya Manusia Kabupaten Serang meliputi:

Identifikasi Lingkungan Internal

- Kekuatan yang diperoleh dalam pelaksanaan implementasi pola karier merupakan terbukanya peluang pengembangan diri melalui diklat fungsional, diklat struktural, asesmen dan tugas belajar;

- Kelemahan terjadi dikarenakan hak prerogratif kepala daerah yang dominan memengaruhi keberhasilan program serta minimnya anggaran dalam perekaman jejak pegawai.

Identifikasi Lingkungan Eksternal

- Peluang yang diharapkan dengan banyaknya regulasi tentang pola karier dapat didukung dengan pengawasan oleh lembaga pemerintah;
- Ancaman implementasi kebijakan pola karier merupakan belum adanya pilot project yang ditunjuk oleh pemerintah pusat yang berdampak kurang tegasnya kepala daerah serta terancam akan digantikan dengan kebijakan baru.

3. Upaya yang dilakukan dalam Implementasi Kebijakan Pola Karier Pegawai NegeriSipil Badan Kepegawaian Pengembangan Sumber Daya Manusia Kabupaten Serang meliputi:

a. Menggunakan pihak ketiga berupa pelaksanaan uji kompetensi untuk eselon II dan fasilitas lainnya seperti diklat struktural fungsional dan keahlian dengan menggunakan pola pengiriman;

b. Meningkatkan Insentif PNS sebagai upaya memenuhi kepentingan pribadi, organisasi atau kebijakan substantif; dan

c. Mempertahankan kinerja dan membagi pola karier lingkup Pemerintah Kabupaten Serang dan menjadi pilot project berskala nasional. 


\section{SARAN}

Berdasarkan simpulan dari hasil penelitian di atas, maka peneliti mengajukan beberapa saran sebagai berikut.

1. Merumuskan suatu kebijakan baru yang mengulas tuntas mengenai implementasi pola karier serta menyosialisasikan kepada seluruh pegawai negeri sipil Kabupaten Serang dan mendapat dukungan dari pihak yang memiliki kewajiban untuk mengawasi kegiatan tersebut;

2. Memperkuat anggaran dalam pelaksanaan Implementasi Pola Karier sehingga mampu meningkatkan kualitas Sumber Daya yang menunjang dan berpengalaman dalam aspek pendukung;

3. Meyakinkan Pengambil Kebijakan akan pentingnya Imlementasi Pola karier yang baik agar dapat terlaksana Birokrasi baik, bersih dan terarah sesuai keahlian pegawai masing-masing;

4. Menjadikan Badan Kepegawaian Pengembangan Sumber Daya Manusia sebagai contoh dalam melaksanakan Implementasi Kebijakan Pola Karier dan menjadi komitmen baik bagi seluruh pegawai Kabupaten Serang.

5. Terus mengoptimalkan pelaksanaan implementasi pola karier sehingga berjalan sesuai ketentuan, selain itu terus melakukan pengembangan kompetensi kepada pegawai.

6. Perlu mengusulkan peninggkatan anggaran Pada berikutnya.

7. Menerapkan peluang yang membuat pegawai selalu memiliki kemudahan dalam implementasi kebijakan pola karier sesuai diamanatkan regulasi yang sudah ada dalam pengawasan lembaga pemerintahan yang transparansi;

8. Diharapkan peningkatan mutu kualitas Pemerintahan Kabupaten Serang yang diatur jelas oleh Pengatur Kebijakan sehingga Badan Kepegawaian

Pengawasan Sumber Daya Manusia dapat menjadi Pilot Project.

\section{DAFTAR RUJUKAN}

A. Muri Yusuf. 2014. Metode Penelitian Kualitatif,Kuantitatif \& Penelitian gabungan. Jakarta: Prenadamedia Group

Agustino, Leo. 2008. Dasar-Dasar Kebijakan. Bandung: Publik Alfabeta. Hlm: 195

Ambar, Teguh Sulistiyani. 2003. Management Sumber Daya Manusia. Hal 9

Bungin, M. Burhan, 2011. Penelitian Kualitatif, Komunikasi, Ekonomi, Kebijakan Publik, dan Ilmu Sosial,Jakarta: Kencana Prenada Media Group.

Bryson, Jhon M. 2016. Perencanaan Strategis bagi Organisasi Sosial. Yogyakarta: Pustaka Pelajar.

Creswell, John W. 2017. Research Design (Pendekatan Kualitatif, Kuantitatif, \& Mixed). Yogyakarta: Pusat Pelajar. Hlm 5

Efendi, Khasan.2010. Memadukan Metode Kuantitatif \& Kualitatif. Bandung: CV Indra Prahasta, Hlm: 147

Freddy Rangkuti. Teknik Membedah Kasus Bisnis Analisis SWOT. Jakarta: Gramedia Pustaka Utama.

Handoko, T. Hani. 2001. Manajemen Personalia dan Sumber Daya Manusia. Yogyakarta: BPFE

Hasibuan, Malayu, S.P. 2005. Manajemen Sumber Daya Manusia. Jakarta: PT Bumi Aksara

I Nyoman Sumaryadi, 2010. Sosiologi Pemerintahan, Ghalia Indonesia, Bogor, HIm: 20.

Irianto.Jusuf. 2001. Manajemen Sumber Daya Manusia, Surabaya: Insan Cendekia

Kadarisman, M. 2013. Manajemen Pengembangan sumber Daya Manusia.jakarta: Rajawali Pers

Kaswan. 2013. Pelatihan dan Pengembangan untuk Meningkatkan Kinerja SDM. Bandung: Alfabeta 
Mangkunegara, A.A. Anwar Prabu. 2010. Perencanaan dan Pengembangan Sumber Daya Manusia. Bandung: PT Refika Aditama

Miles, B.B. dan A.M. Huberman, 2009. Analisis Data Kualitatif. Jakarta: UI Press

Moleong, Lexy J. 2011. Metodologi Penelitian Kualitatif. Bandung: PT Remaja Rosdakarya

Nazir, Moh. 2014. Metodologi Penelitian. Bogor: Ghalia Indonesia.Hlm: 70

Ndraha, Taliziduhu. 2002. Pengantar Teori Pengembangan Sumber Daya Manusia. Jakarta: Rineka Cipta

Rivai,Veithzal. 2003. Manajemen sumber Daya Manusia untuk Perusahaan dari Teori ke Praktik. Jakarta: Rajawali Pers

Riant, Nugroho D. 2012. Public Policy. Surakarta: Gramedia, hlm: 674-675

Simamora, Henry. 2001. Manajemen SDM. Yogyakarta: STIE YKPN

Silalahi, Ulber. 2012. Metode Penelitian Sosial. Bandung: Refika Aditama

Suharsaputra, Uhar. 2012. Metode Penelitian: Kuantitatif, Kualitatif dan Tindakan. Bandung: PT Refika Aditama

Sutrisno, Edy. 2009. Manajemen Sumber Daya Manusia. Jakarta: Kencana

Sugiyono. 2011. Metode Penelitian Kualitatif, Kuantitatif dan R\&D. Bandung: Alfabeta

Sumanto. Teori \& Aplikasi Penelitian. Jakarta: Buku Serasi, Hal 179.

Sumaryadi, I Nyoman. 2016. Paradigma Baru Good Governance, Menempatkan Rakyat dan Birokrasi Pemerintah, Private Sector sebagai Pusat Kegiatan Pemerintahan: Reformasi Birokrasi Pemerintahan Menuju Tata Kelola Pemerintahan Yang Baik. Jatinangor: IPDN Press

Smith, Andrew. 2000. Training \& Development in Australia. Hlm: 2

Syafi, Wirman \& Irawan Setyoko. 2010. Implementasi Kebijakan Publik \& Estetika Profesi Pamong Praja. Sumedang: Jatinangor: Alqaprint, hlm: 35-42
Thoha, Miftah. 2000. Peranan Administrasi Publik dalam Mewujudkan Tata Kepemerintahan yang Baik. Yogyakarta: UGM

Uhar, Syharsaputra, 2012. Metode Penelitian (Kualitatif, Kuantitatif \& Tindakan) Bandung: Refika Aditama. Hal 18.

W. Gulo. 2010. Metodologi Penelitian, Jakarta: Gramedia. Hlm: 99

Wasistiono, Sadu. 2001. Kapita Selekta Manajemen Pemerintahan Daerah. Jatinangor: Alqaprint

Winarno, Budi, 2014, Kebijakan Publik: Teori, Proses, dan Studi Kasus, Center of Academic Publishing Service (CAPS), Yogyakarta.

Wibowo, 2014, Manajemen Kinerja, Edisi ke-4. PT Raja Grafindo persada, Jakarta.

\section{Jurnal/Karya Ilmiah}

Buckley and Caple. 1990. Performance Appraisal: Questions and Answers. Occasional Papers 9. Canberra: Australian Government Publishing Service

Dhermawa, Anak Agung Ngurah Bagus, I Gde Adnyana Sudibya, dan I Wayan Mudiartha Utama. 2012. Pengaruh Motivasi, Lingkungan Kerja, Kompetensi, dan Kompensasi Terhadap Kepuasan Kerja dan Kinerja Pegawai Di Lingkungan Kantor Dinas Pekerjaan Umum Provinsi Bali. Jurnal Manajemen, Strategi Bisnis, dan Kewirausahaan Vol. 6, No. 2 Agustus 2012

Efendi, Nur. 2015. Pengembangan Sumber Daya Manusia Berbasis Kompetensi di Kantor Pemerintah Kota Bandar Lampung. Mimbar, Vol. 31 No. 1. Juni 2015: 1-10

Keban, Yeremias T. 2000. Good Governance dan Capacity Building sebagai Indikator Utama dan Fokus Penilaian Kinerja Pemerintahan. Jakarta: Jurnal Perencanaan Pembangunan.

Muspawi, Mohammad. 2017. Menata Pengembangan Karier Sumber Daya Manusia Organisasi. Jurnal Ilmiah universitas Batanghari Jambi Vol.17 No. 1 Tahun 2017: 1-9 
Puspitapuri, Wulan. Pegawai Negeri Sipil: Pola Karier sesuai Perspektif Undang-Undang Aparatur Sipil Negara No. 5 Tahun 2014. Jurnal Administrasi Publik 2017: 2-22

Rasyid Ryaas. 1998. Kebijakan Penyiapan Sumber Daya Aparatur Yang Profesional dalam Pelaksanaan Otonomi Daerah, Jakarta: Jurnal Ilmu Pemerintahan IIP

\section{Peraturan Perundang-Undangan}

Undang-Undang No. 5 Tahun 2014 tentang Aparatur Sipil Negara

Undang-Undang No. 23 Tahun 2014 tentang Pemerintahan Daerah

Undang-Undang No. 43 Tahun 1999 tentang Pokok-Pokok Kepegawaian
Peraturan Pemerintah No. 11 Tahun 2017 tentang Manajemen Pegawai Negeri Sipil

Peraturan Daerah Kabupaten Serang No. 11 Tahun 2016 tentang Pembentukan dan Susunan Perangkat Daerah Kabupaten

Peraturan Daerah Kabupaten Serang No. 15 Tahun 2006 tentang Pokok-Pokok Pengelolaan Keuangan Daerah

Peraturan Bupati No. 70 Tahun 2016 tentang Struktur Organisasi dan Tata Kerja Badan Kepegawaian Pengembangan Sumber Daya Manusia Kabupaten Serang

Peraturan Bupati No. 68 Tahun 2017 tentang Pedoman Pola Karier 